\title{
Effect of hydrothermal corrosion on the fracture strength of SiC layer in TRISO fuel particles
}

DOI:

10.1111/jace.16369

\section{Document Version}

Accepted author manuscript

Link to publication record in Manchester Research Explorer

\section{Citation for published version (APA):}

Xie, X., Liu, B., Guo, Y., Liu, R., Zhao, X., Ni, N., Guo, F., \& Xiao, P. (2019). Effect of hydrothermal corrosion on the fracture strength of SiC layer in TRISO fuel particles. Journal of the American Ceramic Society.

https://doi.org/10.1111/jace.16369

\section{Published in:}

Journal of the American Ceramic Society

\section{Citing this paper}

Please note that where the full-text provided on Manchester Research Explorer is the Author Accepted Manuscript or Proof version this may differ from the final Published version. If citing, it is advised that you check and use the publisher's definitive version.

\section{General rights}

Copyright and moral rights for the publications made accessible in the Research Explorer are retained by the authors and/or other copyright owners and it is a condition of accessing publications that users recognise and abide by the legal requirements associated with these rights.

\section{Takedown policy}

If you believe that this document breaches copyright please refer to the University of Manchester's Takedown Procedures [http://man.ac.uk/04Y6Bo] or contact uml.scholarlycommunications@manchester.ac.uk providing relevant details, so we can investigate your claim.

\section{OPEN ACCESS}




\section{Effect of hydrothermal corrosion on the fracture strength of $\mathrm{SiC}$ layer in TRISO fuel particles}

Xin Xie ${ }^{1}$, Bing Liu ${ }^{2}$, Yi Guo ${ }^{3}$, Rongzheng Liu $^{2}$, Xiaofeng Zhao ${ }^{1, *}, \mathrm{Na} \mathrm{Ni}^{4, *}$, Fangwei Guo ${ }^{1}$, and Ping Xiao ${ }^{3,1}$

${ }^{1}$ Shanghai Key Laboratory of Advanced High-temperature Materials and Precision Forming, Shanghai Jiao Tong University, Shanghai 200240, China

${ }^{2}$ Key Laboratory of Advanced Reactor Engineering and Safety, Ministry of Education, Tsinghua University, Beijing 100084, China

${ }^{3}$ School of Materials, University of Manchester, MSS Tower, Manchester M13 9PL, United Kingdom

${ }^{4}$ Gas Turbine Research Institute, Shanghai Jiao Tong University, Shanghai 200240, China

${ }^{*}$ Author to whom correspondence should be addressed.

Corresponding author: Xiaofeng Zhao

E-mail: xiaofengzhao@sjtu.edu.cn

Corresponding author: $\mathrm{Na} \mathrm{Ni}$

E-mail: na.ni@sjtu.edu.cn 


\begin{abstract}
The hydrothermal corrosion behavior of $\mathrm{SiC}$ layer in tristructural-isotropic (TRISO) fuel particles and its effect on the fracture strength were investigated. The corrosion test was performed using the static autoclave at $400{ }^{\circ} \mathrm{C} / 10.3 \mathrm{MPa}$. The $\mathrm{SiC}$ layer exhibited a thickness loss and the corrosion rate followed a linear law. During corrosion, carbon was formed on the $\mathrm{SiC}$ surface due to the loss of $\mathrm{Si}$. The corrosion was found preferentially occurred at the grain boundary of $\mathrm{SiC}$, leading to the grain detachment and pit formation. The rate determining step of the corrosion was $\mathrm{SiO}_{2}$ formation rather than $\mathrm{SiO}_{2}$ dissolution in the hydrothermal environment. The fracture strength of $\mathrm{SiC}$ shell after corrosion was evaluated using the crush test. It showed a slight decrease with an increase of corrosion time, due to the thickness reduction of SiC layer. The results of this study demonstrated that the SiC in TRISO particles has good corrosion resistance in the hydrothermal environment.
\end{abstract}

\title{
Keywords
}

silicon carbide, fuel particle, hydrothermal corrosion, fracture strength 


\section{Introduction}

The tristructural-isotropic (TRISO) fuel particles developed for high temperature reactors (HTRs) are known for their superior high-temperature tolerance and extraordinary stability under neutron irradiation. ${ }^{1,2}$ These advantages also render TRISO particles a high potential for use in light water reactors (LWRs). Particularly after the Fukushima Dai-ichi nuclear power plant accident, the current $\mathrm{Zr}$ alloy claddings do not have sufficient accident tolerance to guarantee fuel safety in a typical loss of coolant accident scenario, which has sparked renewed interest in exploring the fuel system to improve the safety of LWRs under accident conditions. ${ }^{3}$ Consequently, the research efforts to use TRISO particles in LWRs are significantly increasing over the past few years. ${ }^{4-6}$

Currently, a new fuel system for LWRs called fully-ceramic microencapsulated fuel (FCM) has been proposed. ${ }^{5}$ It consists of TRISO particles dispersed in SiC matrix to form the fuel compact, which can then be loaded in the nuclear cladding. Under the normal operation condition of LWRs, the TRISO particles are isolated from water coolant by several protective barriers. However, once the cladding breakage should happen, the TRISO particles might be exposed to the water coolant. The hydrothermal corrosion could cause degradation of the structural integrity and the mechanical properties of the outer layers, which would result in fuel damage and disastrous safety problems. Additionally, interest in using $\mathrm{SiC}$ as the nuclear fuel cladding material in LWRs has increased considerably. ${ }^{7}$ Therefore, the hydrothermal corrosion of SiC layers 
of TRISO particles in water coolant at high temperature and pressure should be investigated before this material can be deployed in LWRs.

In recent years, there have been many reports on the hydrothermal corrosion of bulk $\mathrm{SiC}$ in relation to its application as fuel cladding in LWRs. ${ }^{8-13}$ However, the SiC layer on spherical substrate which is the case for TRISO particles exhibited different microstructure and mechanical properties from that of $\mathrm{SiC}$ bulk. ${ }^{14}$ Until now, the corrosion and mechanical behaviors of $\mathrm{SiC}$ layers in TRISO particles in the hydrothermal environment have not been elucidated. Therefore, in this study, the corrosion behavior of $\mathrm{SiC}$ layers of TRISO particles was investigated in the static autoclave. The fracture strength of SiC layers after corrosion was also studied, which is essential for the design and performance analysis of TRISO particles.

\section{Experimental procedure}

The TRISO particles were provided by the University of Manchester made by fluidized bed chemical vapor deposition using zirconia particles with a diameter about $500 \mu \mathrm{m}$ as simulated kernels. ${ }^{15}$ They were prepared without the OPyC layers, the average thickness of the buffer, IPyC, and SiC layers were 200, 40, and $21 \mu \mathrm{m}$, respectively.

\subsection{Hydrothermal corrosion}

The corrosion test was carried out in the static autoclave. The TRISO particles were exposed to the high temperature and pressure water $\left(400{ }^{\circ} \mathrm{C} / 10.3 \mathrm{MPa}\right)$ with a $\mathrm{pH}$ = 7.0-7.2 for up to twelve days. No boric acid and $\mathrm{LiOH}$ were added to the water chemistry condition and the water environment was deaerated to a low oxygen content. 
Due to the variations in the shape and size of TRISO particles, large errors involve in measuring the weight change of TRISO particles. In order to evaluate the corrosion kinetics more accurately, the hemispherical $\mathrm{SiC}$ shell obtained by burning off the PyC layer was also added during the corrosion test and the thickness change of the separated SiC shell was used as a measure of the corrosion degree. The thickness measurement was performed every 3 days of corrosion using an optical microscope.

\subsection{Crush testing}

After corrosion, the TRISO particles were embedded in epoxy and grinded to the mid-plane of the particles using 240, 600, 1200, and 2000 grit SiC papers, then polished using increasingly fine diamond suspensions. The hemisphere particles were heated at $700{ }^{\circ} \mathrm{C}$ for 10 hours in air to burn off the PyC layers and obtained free-standing hemispherical SiC shells whose strength represent the strength of the whole particles. ${ }^{16}$

A modified crush testing was carried out for the hemispherical shells in a universal mechanical testing machine (Z020; Zwick/Roell, Ulm-Einsingen, Germany). For each condition, 30 hemispherical shells were selected and tested at room temperature with a crosshead speed of $0.005 \mathrm{~mm} / \mathrm{s}$. Figure 1 illustrates the process of the test. A SiC shell (out radius $R$, thickness $\delta$ ) was diametrically loaded between a plunger and a testing bed by an external load $F$. An annealed brass foil was inserted between the $\mathrm{SiC}$ shell and plunger which ensured a more uniform stress distribution on the circular contact area (radius $r_{0}$ ). According to the result of finite element analysis, it was essential to have the contact area with a reasonable size for an accurate evaluation of the fracture strength. ${ }^{17}$ If the contact area was too small, measurement errors would be prohibitively 

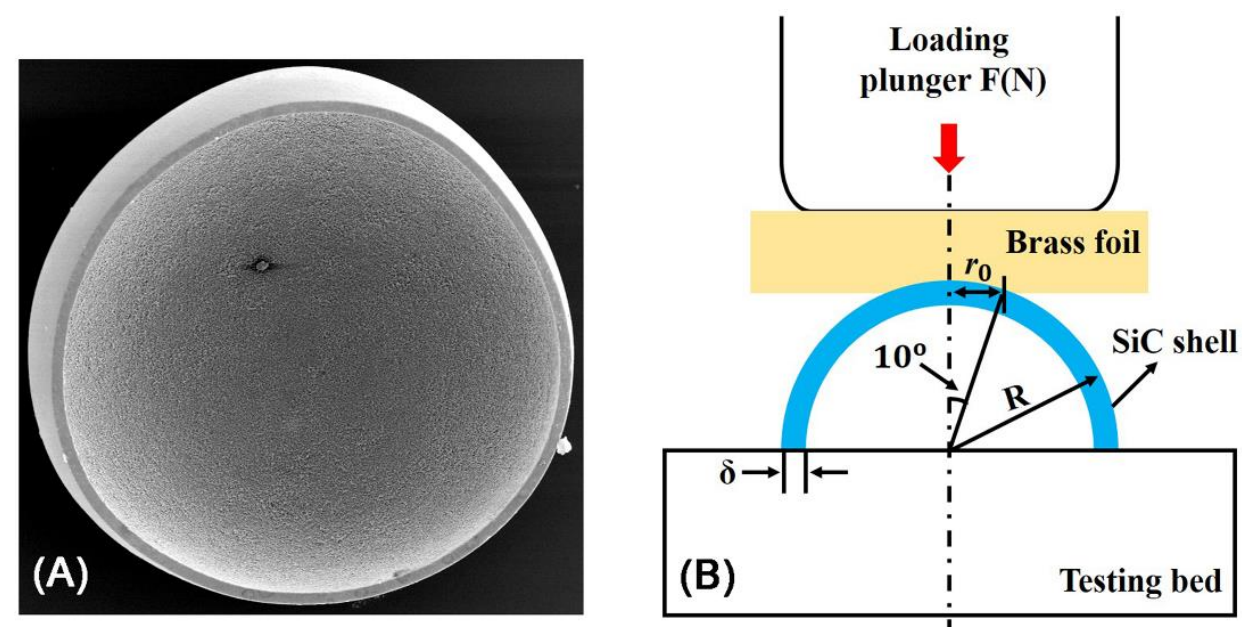

Figure 1 (A) SEM image of a SiC hemispherical shell and (B) schematic sketch of the crush test system

large. However, if the contact area was too large, the maximum principal stress failed to reach the inner apex of $\mathrm{SiC}$ shell, which would greatly affect the accuracy of the result. It was required that the angle between the vertical direction and radius direction should not be more than $10^{\circ}$ (as shown in Figure 1). Therefore, by using the brass foil that has a proper hardness $\left(71 \mathrm{HV}_{0.05}\right)$ after a heat treatment $\left(425^{\circ} \mathrm{C}, 1 \mathrm{~h}\right)$, the contact area can reach a reasonable size $\left(r_{0}: 60 \mu \mathrm{m}-85 \mu \mathrm{m}\right)$.

The fracture strength of $\mathrm{SiC}$ shell can be calculated from the testing results according to the approach as reported in the previous study. ${ }^{18} \mathrm{~A}$ brief summary is given here. The maximum local fracture strength $\left(\sigma_{f}^{L}\right)$ at the inner apex of $\mathrm{SiC}$ shell is a combination of the maximum membrane stress and bending stress, which can be calculated using the following equations ${ }^{18,19}$ :

$$
\begin{gathered}
\sigma_{f}^{L}=\sigma_{\text {membrane }}-\sigma_{\text {bending }} \\
\sigma_{\text {membrane }}=-C_{1} \frac{F \sqrt{1-v^{2}}}{\delta^{2}}
\end{gathered}
$$




$$
\begin{gathered}
\sigma_{\text {bending }}=-C_{2} \frac{F \sqrt{1+v}}{\delta^{2}} \\
C_{1}=0.2205-0.04 \mu-0.0115 \mu^{2} \\
C_{2}=1.2044 e^{(-1.2703 \mu)} \\
\mu=r_{0}\left[\frac{12\left(1-v^{2}\right)}{R^{2} \delta^{2}}\right]^{\frac{1}{4}}
\end{gathered}
$$

where $v$ is the Poisson ratio, $\delta$ is the thickness of shell, $F$ is the applied load, $C_{1}$ and $C_{2}$ are the intermediate coefficients, $\mu$ is the intermediate variable, $r_{0}$ is the radius of the circular contact area, and $R$ is the outer radius of the shell.

Weibull distribution function is the most widely used method to analyze the distribution of the local fracture strength. Using Weibull's two-parameter distribution, the cumulative probability of failure $(P)$ is presented by ${ }^{18,19}$ :

$$
P=1-\exp \left[-S_{\mathrm{E}}\left(\frac{\sigma_{f}}{\sigma_{0}}\right)^{m}\right]
$$

where $\sigma_{f}, m, \sigma_{0}$, and $S_{\mathrm{E}}$ are the local fracture strength, the Weibull modulus, the characteristic strength and the size effect factor, respectively. The size effect factor $S_{\mathrm{E}}$ can be calculated using following expression ${ }^{18,19}$ :

$$
S_{\mathrm{E}}=\pi r_{0}^{2}
$$

Equation (7) can be rewritten in a linear form ${ }^{18,19}$ :

$$
\ln \left[\ln \left(\frac{1}{1-P}\right)\right]=m \ln \sigma_{f}^{L}+\ln \left(\frac{S_{\mathrm{E}}}{\sigma_{0}^{m}}\right)
$$

The Weibull modulus and characteristic strength can be obtained from the slope and intercept terms of the Equation (9) respectively. For each specimen, the value of $P_{i}$ is a prescribed probability estimator rather than a true value. Several probability estimators and their merits have been reported in the previous study. ${ }^{20}$ A conservative probability estimator is given here ${ }^{19}$ : 


$$
P_{i}=\frac{i}{N+1}
$$

where $P_{i}$ is the probability of failure for the ith-ranked stress datum and $N$ is the sample size.

Compared to the local fracture strength, the fracture strength for the full spherical shell $\left(\sigma_{f}^{F}\right)$ is best described as the fracture strength representing the whole shell under a uniform internal stress. Combining the effective surface area and the Weibull modulus, the fracture strength for full spherical shell can be calculated using the following equation $^{18,19}$ :

$$
\sigma_{f}^{F}=\sigma_{f}^{L}\left(\frac{S_{\mathrm{E}}^{L}}{S_{\mathrm{E}}^{F}}\right)^{\frac{1}{m}}=\sigma_{f}^{L}\left[\frac{\pi r_{0}^{2}}{4 \pi(R-\delta)^{2}}\right]^{\frac{1}{m}}
$$

where $\sigma_{f}^{L}, S_{\mathrm{E}}^{L}, \sigma_{f}^{F}$, and $S_{\mathrm{E}}^{F}$ are the fracture strength, and the effective surface for the local loaded area, the fracture strength and the effective surface for the full spherical shell, respectively. Specifically, the coefficient $\pi r_{0}^{2} / 4 \pi(R-\delta)^{2}$ is a scaling factor accounting for the size difference between the localized loading and the uniform internal stress.

\subsection{Characterization}

The thickness of $\mathrm{SiC}$ layer after corrosion was measured at about twenty points using an optical microscope (BX51M, Olympus, Japan). The microstructure of SiC layer was studied by scanning electron microscopy (Inspect F50; FEI, Hillsboro, OR) and transmission electron microscope (TEM) (TALOS F200X, FEI, USA). TEM specimen was prepared using focused ion beam (FIB) (GAIA3, Tescan, Czech Republic). The phase and chemical information of the samples was characterized using X-ray diffraction (XRD) (Ultima IV, Rigaku, Japan), Raman spectroscopy (LabRAM 
HR Evolution, Horiba, France) with $532 \mathrm{~nm}$ argon laser and X-ray photoelectron spectroscopy (XPS) (250XI, Thermo ESCALAB, America).

\section{Results}

\subsection{Hydrothermal corrosion kinetics}

Figure 2 shows the thickness change of $\mathrm{SiC}$ shell as a function of corrosion time at $400{ }^{\circ} \mathrm{C} / 10.3 \mathrm{MPa}$. The measurement was performed on the same hemisphere shell at different time of corrosion. At least 10 hemispheres were used for the thickness measurement. The data suggested that the thickness reduction increased slightly with the increase of exposure time and the corrosion of $\mathrm{SiC}$ proceeds at a constant rate following the linear rate law. As shown from the optical images, the SiC shell was hardly corroded and almost kept its integrity, implying that the SiC layers of TRISO particles had good corrosion resistance in the hydrothermal environment.

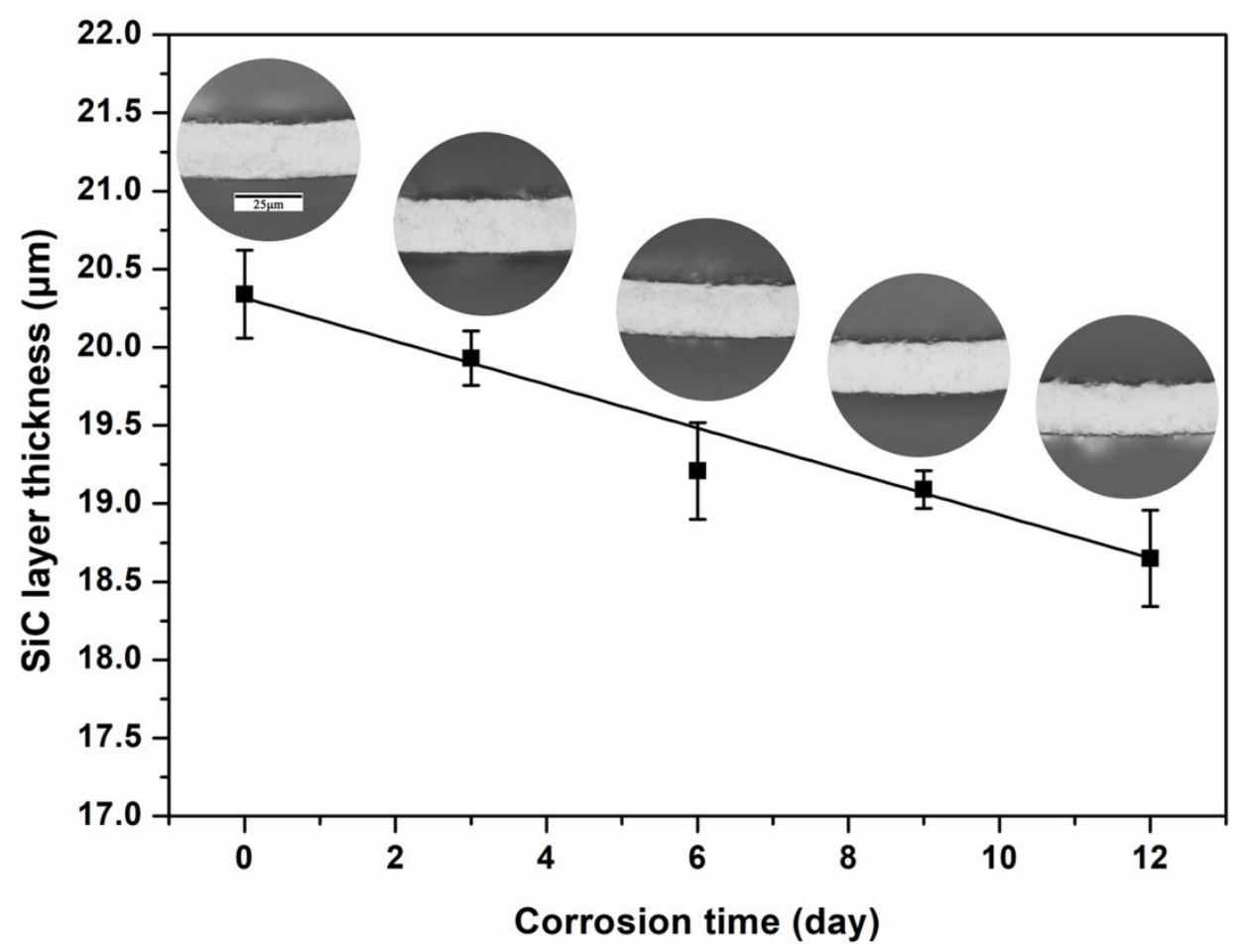

Figure 2 The thickness of $\mathrm{SiC}$ shell as a function of corrosion time 


\subsection{Phase analysis of $\mathrm{SiC}$ layers after corrosion}

The phases of the SiC surface after corrosion were analyzed using XRD and Raman spectroscopy, respectively. Figure 3A shows the XRD patterns for the TRISO particles. Three typical phases could be identified for all the samples, i.e, the $\mathrm{ZrO}_{2}$ kernel, the PyC layer, and SiC layer, respectively. Meanwhile, Raman spectroscopy of the TRISO particles is shown in Figure 3B. The first-order peaks at 796 and $972 \mathrm{~cm}^{-1}$ and second-order peaks at 1540 and $1720 \mathrm{~cm}^{-1}$ correspond to $3 \mathrm{C}-\mathrm{SiC}$. In addition, the D $\left(1350 \mathrm{~cm}^{-1}\right)$ and $\mathrm{G}\left(1600 \mathrm{~cm}^{-1}\right)$ bands in Figure 3C, which belong to the first-order peaks of carbon also appeared after corrosion. With an increase of corrosion time, the amount of carbon increased, as manifested by the intensity ratio between carbon and $\mathrm{SiC}$ peaks. This result is inconsistent with the previous studies, in which no carbon was formed on the surface of the corroded SiC bulk. ${ }^{8-12,21,22}$ The formation of carbon could suggested that the SiC layers of TRISO particles were corroded due to the loss of Si from $\mathrm{SiC}$ layer.
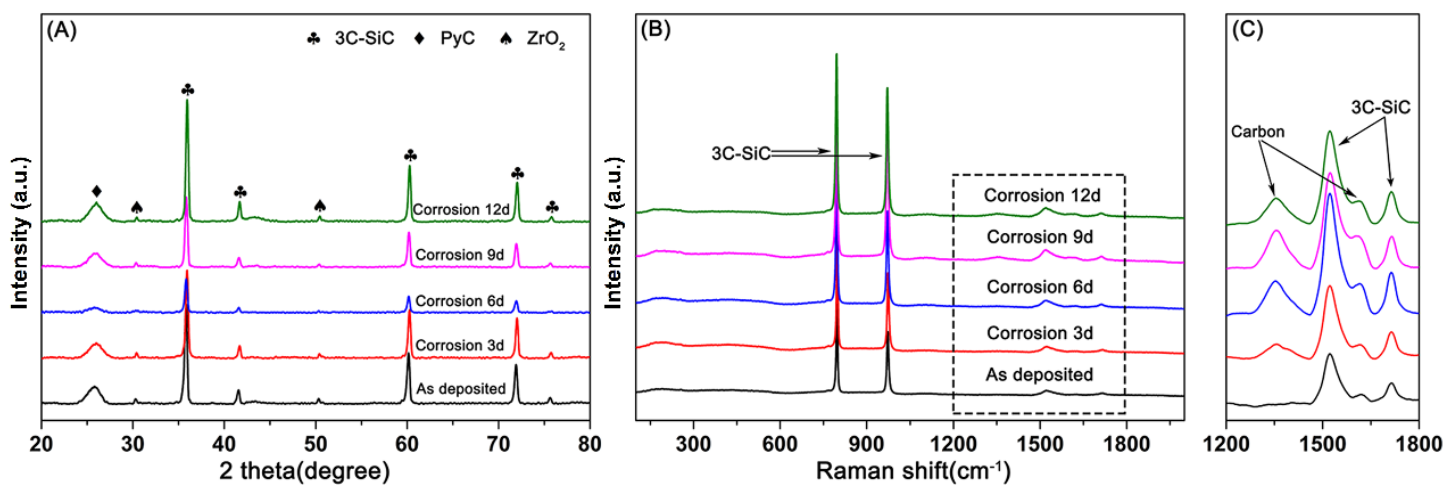

Figure 3 Phase analysis of TRISO particles before and after corrosion, (A) XRD patterns, (B) Raman spectra and (C) detailed spectra from $1200 \mathrm{~cm}^{-1}$ to $1800 \mathrm{~cm}^{-1}$

However, taking into account the thickness of SiC layer and the penetration depth 
of the Raman laser, the appearance and increase intensity of D and G bands may be originated from the inner PyC layers when the thickness of the SiC layer is reduced after corrosion. Therefore, more detailed examination using XPS was employed to analyze whether carbon was indeed formed on the surface of the corroded specimens.
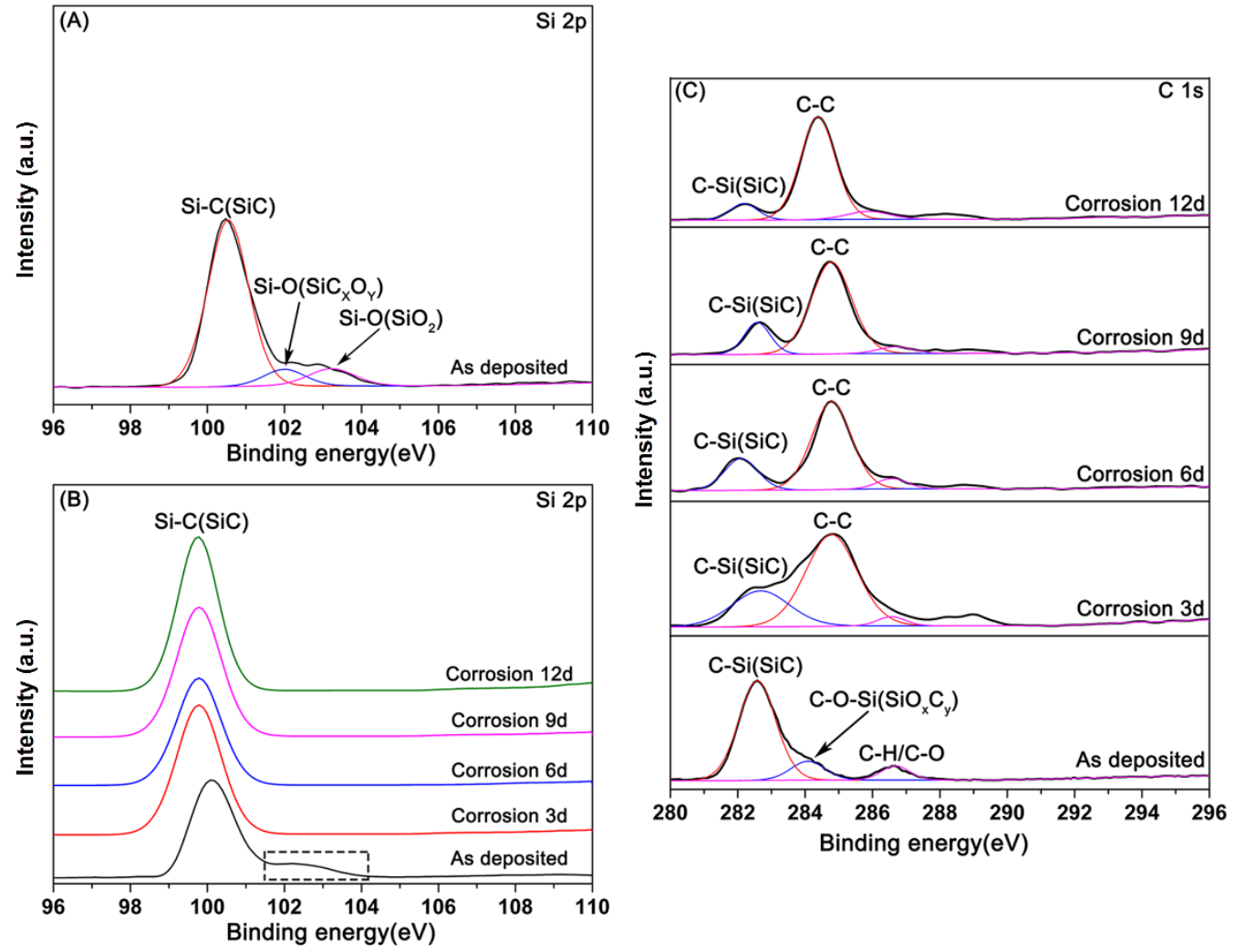

Figure 4 XPS spectra of TRISO particles before and after corrosion, (A) Si 2p peak for the as-deposited specimen, (B) Si 2p peaks for all the specimens and (C) C 1s peaks for all the specimens

Figure 4 shows the XPS spectra from the surface of SiC layer before and after corrosion. For Si $2 p$ peaks (Figure 4A), the line of as-deposited specimen was fitted to three chemical states at $100.54,102.2$, and $103.2 \mathrm{eV}$, which were attributed to $\mathrm{SiC}$, $\mathrm{SiO} x \mathrm{C} y$ and $\mathrm{SiO}_{2}$, respectively. ${ }^{10,23}$ The $\mathrm{Si} 2 \mathrm{p}$ peaks corresponding to the $\mathrm{SiO} x \mathrm{C} y$ and $\mathrm{SiO}_{2}$ completely disappeared after corrosion of 3 days, as shown in Figure 4B. The 
disappearance of $\mathrm{SiO}_{2}$ peak after corrosion is in agreement with the results reported for the water corrosion of bulk SiC. ${ }^{9-11,13}$ For C 1s peaks (Figure 4C), significant differences between the as deposited specimen and the corroded specimens were observed. The C 1s peaks of the as-deposited specimen can be distinguished by three peaks, which were observed at 282.5, 284.08 and $286.48 \mathrm{eV}$ correspond to the existence of $\mathrm{SiC}, \mathrm{SiO} x \mathrm{C} y$ and surface absorption impurity $(\mathrm{C}-\mathrm{O} / \mathrm{C}-\mathrm{H})$, respectively. ${ }^{24,25}$ After 3 days of corrosion, the peak belonging to the C-O-Si bond of $\mathrm{SiO} x \mathrm{C} y$ centered at 284.08 $\mathrm{eV}$ disappeared while a new peak was formed at $284.6 \mathrm{eV}$, which can be attributed to the C-C bond of carbon. The results suggested the formation of a carbon-rich surface due to the loss of Si from the SiC layer, which is consistent with the Raman analyses. In addition, the $\mathrm{C} 1 \mathrm{~s}$ peaks were similar for all the corroded specimens, regardless of the corrosion time. As concluded from Figure 3 and Figure 4, carbon was formed but no sign of any silicon oxides (e.g., $\mathrm{SiO}_{2}$ ) was detected on the surface of the corroded specimens.

\subsection{The microstructure of the SiC layers}

Figure 5 shows the surface and cross-sectional microstructure of SiC layers of TRISO particles after corrosion at $400{ }^{\circ} \mathrm{C} / 10.3 \mathrm{MPa}$ for different time. The surface of as-deposited $\mathrm{SiC}$ layer exhibited both a faceted structure with large grains and a globular-like structure with small grains (Figure 5A). After 3 days of corrosion, the surface morphology was still similar to the as-deposited sample (Figure 5B). After 6 days, a slight corrosion occurred and some small grains started being attacked (Figure 5C). In contrast, after 9 days, the small grains were severely attacked and delaminated 
from the surface (Figure 5D). After 12 days, individual large $\mathrm{SiC}$ grains could be distinguished on the surface and a considerable amount of large $\mathrm{SiC}$ grains detached from the surface (Figure 5E). Furthermore, pits were also observed on the surface.
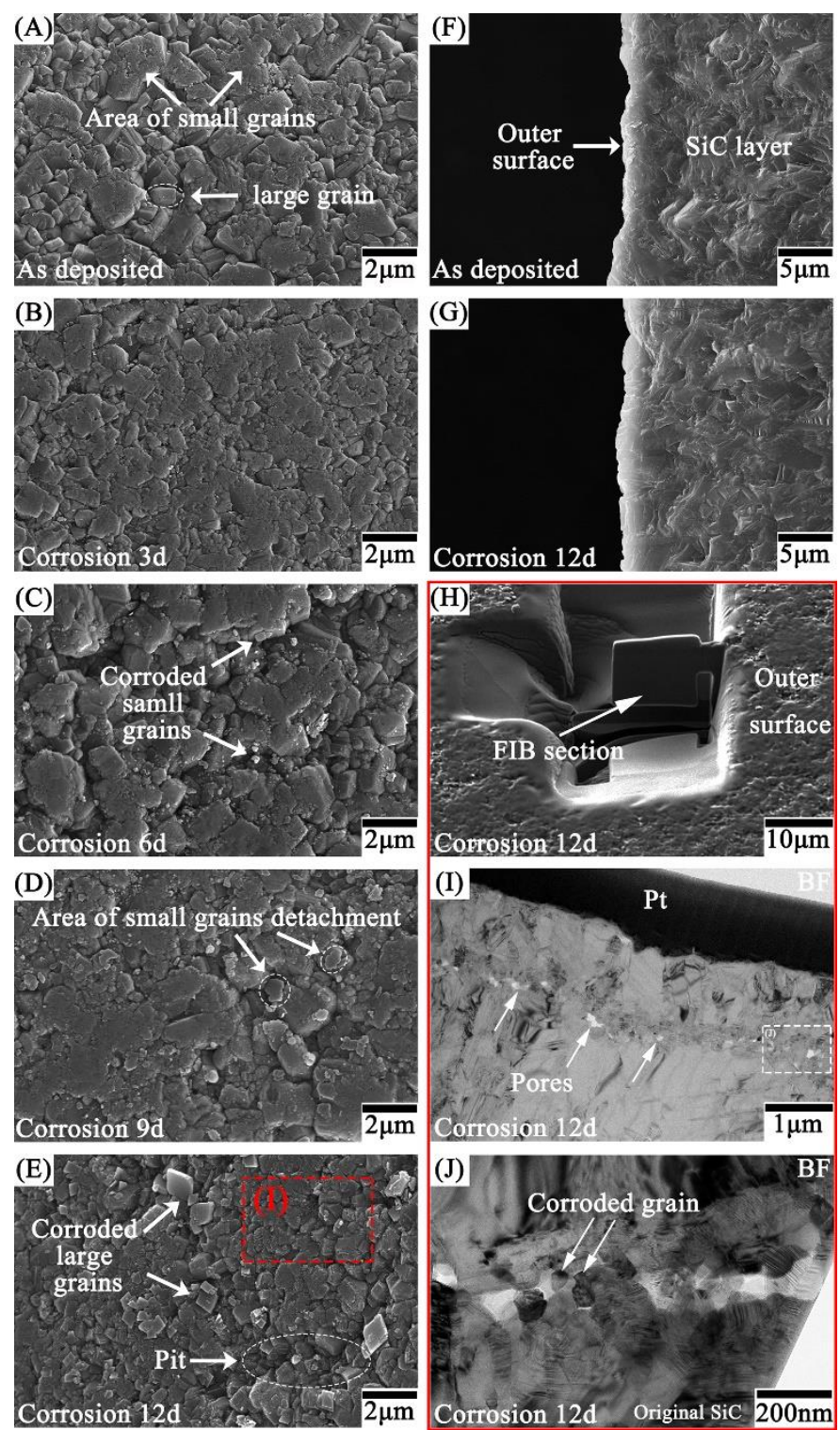

Figure 5 Figure 5 SEM images (A-E) correspond to the SiC surface microstructure after corrosion for different time, $(\mathrm{F})$ and $(\mathrm{G})$ correspond to the $\mathrm{SiC}$ fractured cross sectional microstructure for the as deposited sample and 12 days corroded sample, respectively. (H) the FIB section and (I), (J) the bright-field TEM images for the 12 days corroded sample 
However, no significant variation was observed between the fractured crosssections of the as deposited sample and the 12 days corroded sample, as can be seen from Figure 5F and Figure 5G. Therefore, TEM was employed to further characterize the microstructure of the sample corroded for 12 days. Figure $5(\mathrm{H})$ shows the FIB section, which was taken on the surface of the sample corroded for 12 days. In Figure 5 (I), an obvious corroded layer at the surface of SiC layer was observed. The source of this corroded layer is that portion of the $\mathrm{SiC}$ grains have undergone corrosion and dissolution by the high temperature and pressure water. ${ }^{13}$ In addition, many small pores were also observed at the interface between the corroded layer and the $\mathrm{SiC}$ layer. In Figure $5(\mathrm{~J})$, the corroded grain can be distinguished. These images confirm that the grain boundaries are preferentially attacked.

\subsection{Fracture strength of $\mathrm{SiC}$ shells}

Figure 6 and 7 show the Weibull plots of the local fracture strength $\left(\sigma_{f}^{L}\right)$ and the full fracture strength $\left(\sigma_{f}^{F}\right)$ of the $\mathrm{SiC}$ layer before and after corrosion. Each dataset was linearly fitted to obtain the Weibull modulus $m$ (the slope of the linear fit), which shows the strength distribution. All the results of the crush tests were summarized in Table 1. Both the local fracture strength $\left(\sigma_{f}^{L}\right)$ and the full fracture strength $\left(\sigma_{f}^{F}\right)$ tended to decrease slightly with an increasing corrosion time. The average values of the local fracture strength reduced from $1356 \mathrm{MPa}$ to $1281 \mathrm{MPa}$, while those for the full fracture strength reduced from $609 \mathrm{MPa}$ to $590 \mathrm{MPa}$. However, the Weibull modulus revealed similar values from 6.21 to 6.72 for the local fracture strength and 7.13 to 7.77 for the full fracture strength. 


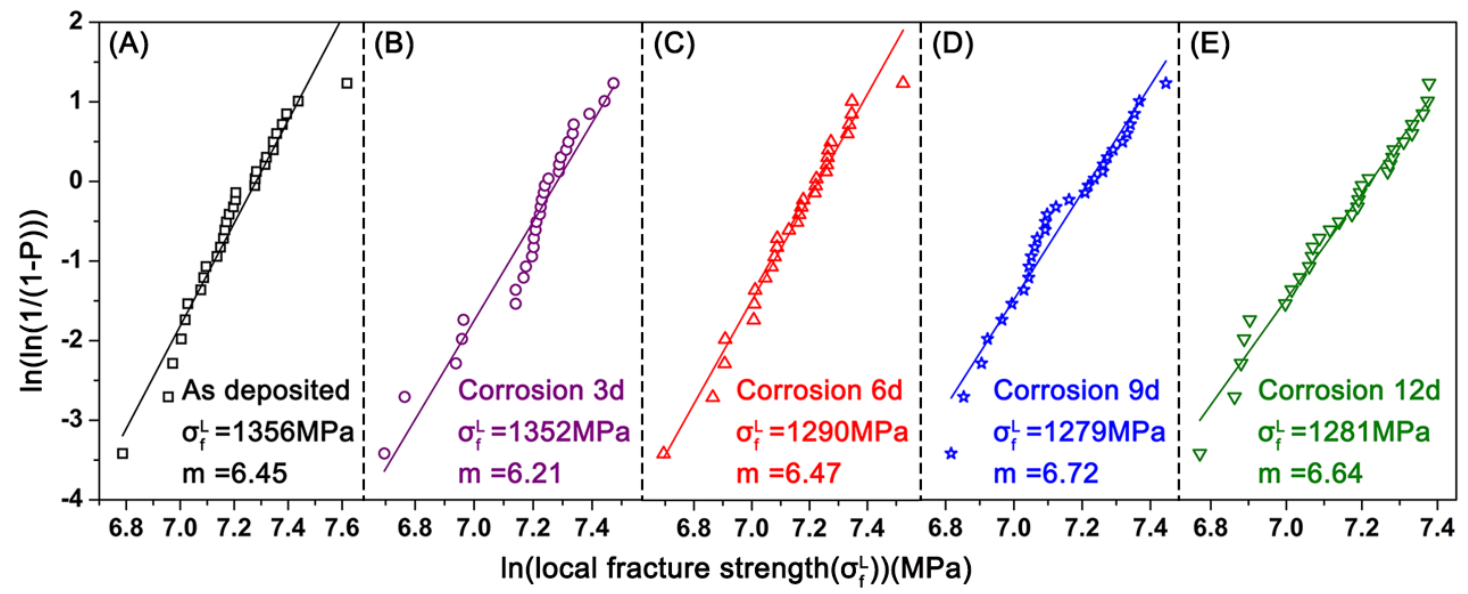

Figure 6 The local fracture strength of SiC shells in the form of Weibull distribution after corrosion for different time

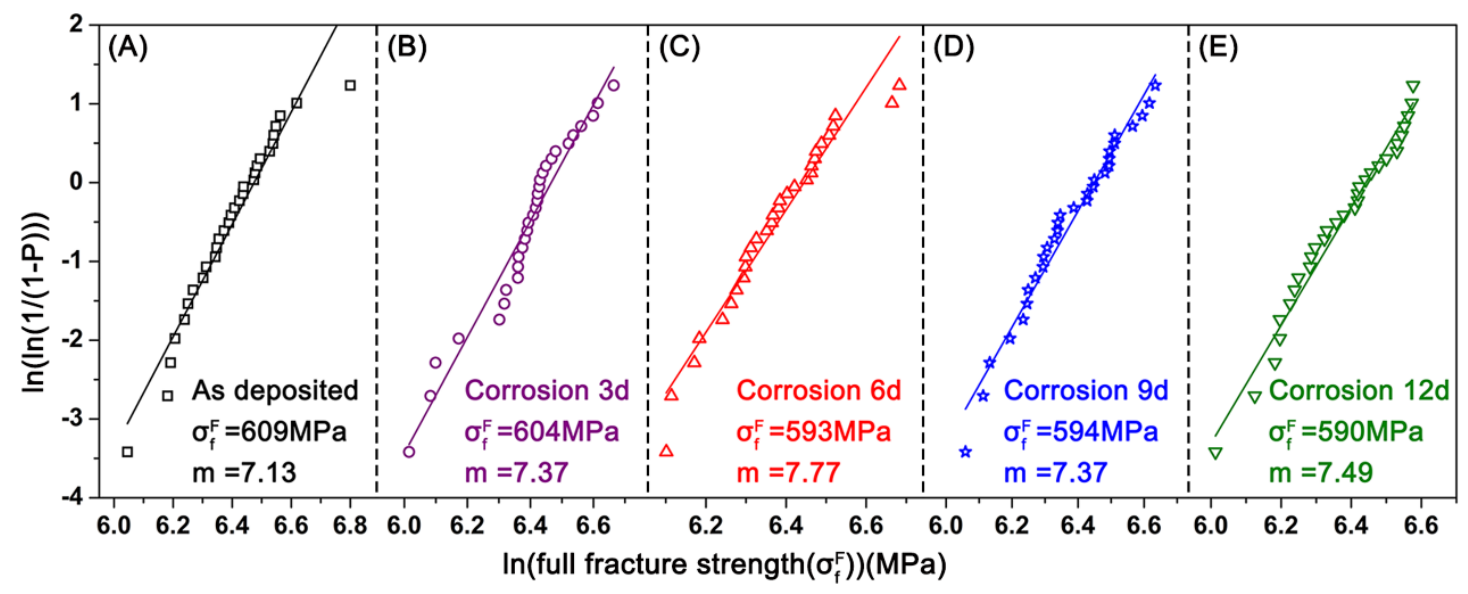

Figure 7 The full fracture strength of SiC shells in the form of Weibull distribution after corrosion for different time

Table 1 Summarized results of the crush tests (with the Weibull modulus given in brackets) of SiC shells after corrosion for different time

\begin{tabular}{ccccc}
\hline Samples & $2 r_{0}(\mu \mathrm{m})$ & $\mathrm{F}(\mathrm{N})$ & $\sigma_{f}^{L}(\mathrm{MPa})$ & $\sigma_{f}^{F}(\mathrm{MPa})$ \\
\hline As deposited & 143.46 & 5.43 & $1356(6.45)$ & $609(7.13)$ \\
3 days & 144.12 & 5.37 & $1352(6.21)$ & $604(7.37)$ \\
6 days & 147.53 & 5.35 & $1290(6.47)$ & $593(7.77)$ \\
9 days & 153.46 & 5.39 & $1279(6.72)$ & $594(7.37)$ \\
12 days & 152.53 & 5.41 & $1281(6.64)$ & $590(7.49)$ \\
\hline
\end{tabular}




\section{Discussion}

\subsection{Corrosion kinetics of $\mathrm{SiC}$ layers}

The hydrothermal corrosion behavior of $\mathrm{SiC}$ has been investigated previously. ${ }^{11-}$ 13, 22, 26 Thermodynamic calculations show that the corrosion of SiC in the hydrothermal environment could occur through the following reactions (12a)-(12d) ${ }^{20}$ :

$$
\begin{gathered}
\mathrm{SiC}+2 \mathrm{H}_{2} \mathrm{O} \rightarrow \mathrm{SiO}_{2}+\mathrm{CH}_{4} \\
\mathrm{SiC}+3 \mathrm{H}_{2} \mathrm{O} \rightarrow \mathrm{SiO}_{2}+\mathrm{CO}+3 \mathrm{H}_{2} \\
\mathrm{SiC}+4 \mathrm{H}_{2} \mathrm{O} \rightarrow \mathrm{SiO}_{2}+\mathrm{CO}_{2}+4 \mathrm{H}_{2} \\
\mathrm{SiC}+2 \mathrm{H}_{2} \mathrm{O} \rightarrow \mathrm{SiO}_{2}+\mathrm{C}+2 \mathrm{H}_{2}
\end{gathered}
$$

In the current study, the formation of carbon suggests that the dominant reaction is Equation (12d). The Gibbs free energy change of reaction $(12 \mathrm{~d})$ at $400^{\circ} \mathrm{C}$ is -320.02 $\mathrm{kJ} / \mathrm{mol}$. Therefore, the rate of $\mathrm{SiO}_{2}$ formation via reaction $(12 \mathrm{~d}), r_{l}$, can be written as:

$$
r_{l}=k_{l}\left(a_{\mathrm{SiC}}\right)\left(a_{\mathrm{H}_{2} \mathrm{O}}\right)^{2}
$$

where $k_{1}, a_{\mathrm{SiC}}$ and $a_{\mathrm{H}_{2} \mathrm{O}}$ are the reaction rate constant, the activity of $\mathrm{SiC}$ and the activity of water, respectively. At the reaction interface, $\mathrm{SiC}$ and water are abundantly available, the activities are assumed to be unity. Therefore, the rate of silica formation $\left(r_{1}\right)$ can be substituted by the reaction rate constant $\left(k_{1}\right)$.

Meanwhile, the $\mathrm{SiO}_{2}$ can be dissolved into water via the following reaction:

$$
\mathrm{SiO}_{2}+\mathrm{H}_{2} \mathrm{O} \rightarrow \mathrm{HSiO}_{3}^{-}+\mathrm{H}^{+} \rightarrow \mathrm{SiO}_{3}^{2-}+2 \mathrm{H}^{+}
$$

In this case, the rate of $\mathrm{SiO}_{2}$ dissolution depends on the $\mathrm{pH}$ of water. As reported in previous studies, the rate of $\mathrm{SiO}_{2}$ dissolution via reaction (14), $r_{n e t}$, will have the general form ${ }^{27-31}$ : 


$$
r_{\text {net }}=k_{f} \frac{A}{M}\left(1-\frac{m}{m_{\text {sat }}}\right)
$$

where $k_{f}(\mathrm{~mol} / \mathrm{kg}-\mathrm{s}), A\left(m^{2}\right), M(\mathrm{~kg}), m$, and $m_{\text {sat }}$ are the forward reaction rate constant, the surface area, the mass of water, the concentration of $\mathrm{SiO}_{2}$ in water, and the solubility limit of $\mathrm{SiO}_{2}$ in water, respectively. It is possible to assume that the concentration of silica in water $(m)$ is insignificant during test. ${ }^{11}$ Therefore, the net rate of silica dissolution $\left(r_{n e t}\right)$ can be substituted by the forward reaction rate constant $\left(k_{f}\right)$.

Table 2 summarizes the reaction rate constants of $\mathrm{SiO}_{2}$ formation $\left(k_{1}\right)$ and $\mathrm{SiO}_{2}$ dissolution $\left(k_{f}\right)$. It can be seen that the $\mathrm{SiO}_{2}$ dissolution rate constant is 4 magnitude higher than the formation rate constant, indicating that the $\mathrm{SiO}_{2}$ formation is the rate determining step for the corrosion of SiC layer in the hydrothermal environment, which gives rise to the observed linear corrosion kinetics. This also means that once $\mathrm{SiO}_{2}$ formed, it dissolves immediately into water. This could explain why no $\mathrm{SiO}_{2}$ was observed on the surface of the corroded SiC layer.

Table 2 Summary of reaction rate constant of $\mathrm{SiO}_{2}$ formation and dissolution

\begin{tabular}{ccc}
\hline $\begin{array}{c}\text { Reaction rate } \\
\text { constant }\left(\mathrm{mol} / \mathrm{m}^{2}-\mathrm{s}\right)\end{array}$ & $\mathrm{SiO}_{2}$ formation $\left(k_{1}\right)^{11}$ & $\mathrm{SiO}_{2}$ dissolution $\left(k_{f}\right)^{27}$ \\
\hline Parameters & $2.49 \times 10^{-9}$ & $3.55 \times 10^{-5}$ \\
\hline
\end{tabular}

\subsection{Microstructure of SiC layers upon hydrothermal corrosion}

In the hydrothermal environment, $\mathrm{SiO}_{2}$ dissolves readily in water and does not maintain an effective protection. Therefore, further corrosion depends on the features of the grain size and grain boundary. For sintered $\mathrm{SiC}$, sintering agents segregate in the grain boundaries and these sintering agents dissolve faster than $\mathrm{SiC}$ grains, resulting in preferential dissolution at the grain boundary. ${ }^{32}$ Previous studies have reported that 
preferential intergranular dissolution was a typical phenomenon in the corrosion behavior of sintered $\mathrm{SiC}$ under hydrothermal conditions, which depended on the manufacturing routes and the sintering agents..$^{8,21,33}$ Compared with sintered bulk SiC, the corrosion of CVD-SiC tends to proceed relatively more uniform because of the higher purity at the grain boundary. ${ }^{34}$ In this study, small SiC grains were observed to be dissolved faster than large ones. This could be related to the larger fractions of grain boundary areas for smaller grains, which makes them to be more susceptible to the reaction with water. ${ }^{9}$ Therefore, large $\mathrm{SiC}$ grains have better corrosion resistance than small ones in the hydrothermal environment. In this manner, the formation of pits can be attributed to the detachment of $\mathrm{SiC}$ grains from the surface. On the other hand, previous investigation had proposed that the formation of pits could be caused by local galvanic cell formation due to hydrolysis reactions involving dissolution of $\mathrm{SiO}_{2}$ and formation of carbon. ${ }^{22}$ This is in agreement with the current work in terms of the carbon formation.

\subsection{Effect of hydrothermal corrosion on the fracture strength of $\mathrm{SiC}$ layers}

As reported in previous studies, the microstructure such as the roughness of IPyC/SiC interface, the porosity, the grain size and the thickness of SiC layer have effects on the fracture strength of the SiC layers in TRISO particles. ${ }^{16,18,32,35-42}$ Byun et al. have evaluated the fracture strength of the $\mathrm{SiC}$ layer using the modified crush test method and concluded that the variation in fracture strength is linked to the inner surface roughness and porosity. ${ }^{18}$ Cromarty and Cao et al both reported that the fracture strength of TRISO particles was proportional to the thickness of SiC layers. ${ }^{16,35}$ 
In this study, the roughness of IPyC/SiC interface and, the porosity of $\mathrm{SiC}$ layer do not show any change after corrosion. The slight decrease in strength may be due to the reduction in the thickness of the $\mathrm{SiC}$ layer. When being tested, the $\mathrm{SiC}$ shell is highly stressed under a circular contact area. Since the fracture strength depends sensitively on the contact area of material stressed, thinner specimen has a smaller effective tested area and tends to have higher stress concentration at the inner surface of the $\mathrm{SiC}$ shell, where crack would initiate, and propagate through the whole $\mathrm{SiC}$ layer resulting in a smaller fracture strength and a smaller Weibull modulus. ${ }^{16,18}$ However, it has to be noted that the crush test is expected to contain considerable experimental errors due to the irregularities and variations in the shape and size of specimens, as pointed out by previous studies. ${ }^{17,18}$ Taking into account the experimental errors, the changes in the full fracture strength (609 $\mathrm{MPa}$ to $590 \mathrm{MPa}$ ) and the Weibull modulus (7.13 to 7.77) suggest that the mechanical strength of the samples decrease slightly or almost unchanged after hydrothermal corrosion.

\section{Conclusions}

The hydrothermal corrosion of SiC layers in TRISO particles was investigated in the static autoclave with the high temperature and pressure water $\left(400{ }^{\circ} \mathrm{C} / 10.3 \mathrm{MPa}\right)$. No $\mathrm{SiO}_{2}$ was detected but carbon was formed on the surface of corroded specimens. The thickness of SiC layer decreased slightly with the increase of the exposure time. The formation of $\mathrm{SiO}_{2}$ was analyzed to be the rate determining step for the corrosion of $\mathrm{SiC}$ layer, leading to the observed linear corrosion kinetics. The corrosion mechanism of $\mathrm{SiC}$ layer was the preferential corrosion at the grain boundary, and the formation of 
pits can be attributed to the detachment of $\mathrm{SiC}$ grains from the surface. The slight decrease in strength values with the increase of corrosion time may be due to the reduction in the thickness of the $\mathrm{SiC}$ layer. These results indicate that the $\mathrm{SiC}$ layers of TRISO particles have exceptionally good corrosion resistance in the hydrothermal environment.

\section{Acknowledgments}

This research was supported by the Natural Science Foundation of China (No.51472157), the "1000 Plan Program", Shanghai Pujiang Program (No. 18PJ1406500) and International Science \& Technology Cooperation Program of China (No. 2016YFE0100700) 


\section{References}

1. Petti DA, Buongiorno J, Maki JT, Hobbins RR, Miller GK. Key differences in the fabrication, irradiation and high temperature accident testing of US and German TRISO-coated particle fuel, and their implications on fuel performance. Nucl Eng Des. 2003;222:281-297.

2. Snead LL, Nozawa T, Katoh Y, Byun T-S, Kondo S, Petti DA. Handbook of SiC properties for fuel performance modeling. J Nucl Mater. 2007;371:329-377.

3. Zinkle SJ, Terrani KA, Gehin JC, Ott LJ, Snead LL. Accident tolerant fuels for LWRs: a perspective. J Nucl Mater. 2014;448:374-379.

4. Terrani KA, Kiggans JO, Katoh Y, Shimoda K, Montgomery FC, Armstrong BL, et al. Fabrication and characterization of fully ceramic microencapsulated fuels. J Nucl Mater. 2012;426:268-276.

5. Terrani KA, Snead LL, Gehin JC. Microencapsulated fuel technology for commercial light water and advanced reactor application. J Nucl Mater. 2012;427:209-224.

6. Snead LL, Terrani KA, Katoh Y, Silva C, Leonard KJ, Perez-Bergquist AG. Stability of SiC-matrix microencapsulated fuel constituents at relevant LWR conditions. J Nucl Mater. 2014;448:389-398.

7. Park DJ, Jung YI, Kim HG, Park JY, Koo YH. Oxidation behavior of silicon carbide at $1200^{\circ} \mathrm{C}$ in both air and water-vapor-rich environments. Corros Sci. 2014;88:416422.

8. Kim W-J, Hwang HS, Park JY, Ryu W-S. Corrosion behaviors of sintered and chemically vapor deposited silicon carbide ceramics in water at $360{ }^{\circ} \mathrm{C}$. J Mater Sci 
Lett. $2003 ; 22: 581-584$.

9. Barringer E, Faiztompkins Z, Feinroth H, Allen T, Lance M, Meyer H, et al. Corrosion of CVD silicon carbide in $500{ }^{\circ} \mathrm{C}$ supercritical water. J Am Ceram Soc. 2007;90:315-318.

10. Kim D, Lee H-G, Park JY, Park J-Y, Kim W-J. Effect of dissolved hydrogen on the corrosion behavior of chemically vapor deposited $\mathrm{SiC}$ in a simulated pressurized water reactor environment. Corros Sci. 2015;98:304-309.

11. Terrani KA, Yang Y, Kim YJ, Rebak R, Meyer HM, Gerczak TJ. Hydrothermal corrosion of $\mathrm{SiC}$ in LWR coolant environments in the absence of irradiation. J Nucl Mater. 2015;465:488-498.

12. Park J-Y, Kim I-H, Jung Y-I, Kim H-G, Park D-J, Kim W-J. Long-term corrosion behavior of CVD SiC in $360{ }^{\circ} \mathrm{C}$ water and $400{ }^{\circ} \mathrm{C}$ steam. J Nucl Mater. $2013 ; 443: 603-607$.

13. Parish CM, Terrani KA, Kim Y-J, Koyanagi T, Katoh Y. Microstructure and hydrothermal corrosion behavior of NITE-SiC with various sintering additives in LWR coolant environments. J Eur Ceram Soc. 2017;37:1261-1279.

14. López-Honorato E, Meadows PJ, Tan J, Xiao P. Control of stoichiometry, microstructure, and mechanical properties in $\mathrm{SiC}$ coatings produced by fluidized bed chemical vapor deposition. J Mater Res. 2008;23:1785-1796.

15. López-Honorato E, Tan J, Meadows PJ, Marsh G, Xiao P. TRISO coated fuel particles with enhanced SiC properties. J Nucl Mater. 2009;392:219-224.

16. Cao F, Hao W, Wang X, Guo F, Zhao X, Rohbeck N, et al. Effects of water vapor 
on the oxidation and the fracture strength of $\mathrm{SiC}$ layer in TRISO fuel particles. J Am Ceram Soc. 2017;100:2154-2165.

17. Davis BC, Ward L, Butt DP, Fillery B, Reimanis I. Fracture strength and principal stress fields during crush testing of the $\mathrm{SiC}$ layer in TRISO-coated fuel particles. J Nucl Mater. 2016;477:263-272.

18. Byun TS, Hunn JD, Miller JH, Snead LL, Kim JW. Evaluation of fracture stress for the SiC layer of TRISO-coated fuel particles using a modified crush test method. Int J Appl Ceram Technol. 2010;7:327-337.

19. Roark RJ, Young WC. Formulas for Stress and Strain, FifthEdn, New York: McGraw-Hill Book Co; 1974.

20. Jacobson NS, Gogotsi YG, Yoshimura M. Thermodynamic and experimental study of carbon formation on carbides under hydrothermal conditions. J Mater Chem. $1995 ; 5: 595-601$.

21. Kim W-J, Hwang HS, Park JY. Corrosion behavior of reaction-bonded silicon carbide ceramics in high-temperature water. J Mater Sci Lett. 2002;21:733-735.

22. Henager CH, Schemer-Kohrn AL, Pitman SG, Senor DJ, Geelhood KJ, Painter CL. Pitting corrosion in CVD SiC at $300{ }^{\circ} \mathrm{C}$ in deoxygenated high-purity water. J Nucl Mater. 2008;378:9-16.

23. Shimoda K, Park J-S, Hinoki T, Kohyama A. Influence of surface structure of SiC nano-sized powder analyzed by X-ray photoelectron spectroscopy on basic powder characteristics. Appl Surf Sci. 2007;253:9450-9456.

24. Yang X, Liu M, Gao Y, Zhang D, Feng S, Liu H, et al. Effect of oxygen on the 
corrosion of SiC in LiF-NaF-KF molten salt. Corros Sci. 2016;103:165-172.

25. Liu R, Liu B, Zhang K, Liu M, Shao Y, Tang C. High temperature oxidation behavior of SiC coating in TRISO coated particles. J Nucl Mater. 2014;453:107114.

26. Terrani KA, Pint BA, Parish CM, Silva CM, Snead LL, Katoh Y. Silicon carbide oxidation in steam up to 2 MPa. J Am Ceram Soc. 2014;97:2331-2352.

27. Tester JW, Worley WG, Robinson BA, Grigseiy CO, Feerer JL. Correlating quartz dissolution kinetics in pure water from 25 to $625^{\circ} \mathrm{C}$. Geochim Cosmochim Acta. $1994 ; 58: 2407-2420$.

28. Dove PM, Czank CA. Crystal chemical controls on the dissolution kinetics of the isostructural sulfates celestite anglesite and barite. Geochim Cosmochim Acta. 1995;59:1907-1915.

29. Icenhower JP, Dove PM. The dissolution kinetics of amorphous silica into sodium chloride solutions effects of temperature and ionic strength. Geochim Cosmochim Acta. 2000;64: 4193-4203.

30. Dove PM, Han N, Wallace AF, De Yoreo JJ. Kinetics of amorphous silica dissolution and the paradox of the silica polymorphs. PNAS. 2008;105:9903-9908.

31. Fleming BA. Kinetics of reaction between silicic acid and amorphous silica surfaces in $\mathrm{NaCl}$ solutions. J Colloid Interface Sci. 1986;110:40-64.

32. Hong S-G, Byun T-S, Lowden RA, Snead LL, Katoh Y. Evaluation of the fracture strength for silicon carbide layers in the tri-isotropic-coated fuel particle. J Am Ceram Soc. 2007;90:184-191. 
33. Hirayama H, Kawakubo T, Goto A, Kaneko T. Corrosion behavior of silicon carbide in $290^{\circ} \mathrm{C}$ water. J Am Ceram Soc. 1989;72:2049-2053.

34. Kondo S, Lee M, Hinoki T, Hyodo Y, Kano F. Effect of irradiation damage on hydrothermal corrosion of SiC. J Nucl Mater. 2015;464:36-42.

35. Cromarty RD, van Rooyen GT, de Villiers JPR. Crush strength of silicon carbide coated TRISO particles: influence of test method and process variables. J Nucl Mater. 2014;445:30-36.

36. Kim W-J, Park JN, Cho MS, Park JY. Effect of coating temperature on properties of the SiC layer in TRISO-coated particles. J Nucl Mater. 2009;392:213-218.

37. Zhang H, López-Honorato E, Xiao P. Effect of thermal treatment on microstructure and fracture strength of SiC coatings. J Am Ceram Soc. 2013;96:1610-1616.

38. Rohbeck N, Xiao P. Effects of thermal treatment on the mechanical integrity of silicon carbide in HTR fuel up to $2200^{\circ} \mathrm{C}$. J Nucl Mater. 2014;451:168-178.

39. Rohbeck N, Xiao P. Evaluation of the mechanical performance of silicon carbide in TRISO fuel at high temperatures. Nucl Eng Des. 2016;306:52-58.

40. van Rooyen GT, Preez Rd, Villiers Jd, Cromarty R. The fracture strength of TRISOcoated particles determined by compression testing between soft aluminium anvils. J Nucl Mater. 2010;403:126-134.

41. van Rooyen IJ, Neethling JH, van Rooyen PM. The influence of annealing temperature on the strength of TRISO coated particles. J Nucl Mater. 2010;402:136146.

42. Hosemann P, Martos JN, Frazer D, Vasudevamurthy G, Byun TS, Hunn JD, et al. 
Mechanical characteristics of SiC coating layer in TRISO fuel particles. J Nucl

Mater. 2013;442:133-142. 